\title{
PENGARUH INDEKS BURSA LUAR NEGERI, INDIKATOR MAKROEKONOMI DAN KRISIS EKONOMI GLOBAL TERHADAP INDEKS HARGA SAHAM GABUNGAN DI INDONESIA
}

\section{THE EFFECTS OF FOREIGN EXCHANGE INDEX, MACROECONOMIC INDICATORS AND GLOBAL ECONOMIC CRISIS ON COMPOSITE STOCK PRICE INDEX IN INDONESIA}

\author{
Aditya $^{*}$, Bonar M. Sinaga ${ }^{* *}$, dan TB. Ahmad Maulana*) \\ *) Sekolah Bisnis, Institut Pertanian Bogor \\ Jl. Raya Pajajaran, Bogor 16151 \\ **) Departemen Ekonomi Sumberdaya dan Lingkungan, Fakultas Ekonomi dan Manajemen, Institut Pertanian Bogor \\ Jl. Agatis Kampus IPB Darmaga Gd. Fakultas Ekonomi dan Manajemen W3L2 Darmaga Bogor 16880
}

\begin{abstract}
The purpose of this study was to analyze the effect of foreign external factors i.e. foreign stock market indicies, world gold prices, and global economic crisis, and domestic external factors i.e. macroeconomic indicators on IHSG. Foreign stock market indices used in this study were DJIA (United States), Nikkei 225 (Japan) and DAX (Germany), while the macroeconomic indicators used included BI rate, inflation rate, and exchange rate of rupiah to USD. Global economic crises involved Subprime Mortgage (America) and European soverign debt (Europe) proxied by dummy crises. The analytical method used in this study was multiple regression analysis on monthly data of 2007-2015 period. The results of this study indicate that DJIA and Nikkei 225 had positively significant effects on IHSG. BI rate, exchange rate of rupiah to USD, and dummy crisis had negative effects on IHSG. Meanwhile, DAX, inflation rate, and world gold price had no significant effects on IHSG.
\end{abstract}

Keywords: foreign stock market indices, macroeconomic indicators, global economic crisis, multiple regression analysis

\begin{abstract}
Abstrak: Penelitian ini bertujuan menganalisis pengaruh faktor eksternal ekonomi luar negeri yaitu indeks harga saham luar negeri, harga emas dunia dan krisis ekonomi global dan faktor eksternal dalam negeri, yaitu indikator makroekonomi terhadap Indeks Harga Saham Gabungan (IHSG) di Indonesia. Indeks harga saham luar negeri yang digunakan adalah DJIA (Amerika), Nikkei 225 (Jepang) dan DAX (Jerman). Indikator makroekonomi yang digunakan adalah BI rate, Inflasi dan Nilai Tukar rupiah terhadap USD. Krisis ekonomi global meliputi krisis Subprime mortgage (Amerika) dan European Soverign Debt (Eropa) yang diproxy oleh dummy krisis. Analisis menggunakan model regresi berganda dan data bulanan periode 2007-2015. Hasil penelitian menunjukkan DJIA dan Nikkei 225 berpengaruh signifikan positif terhadap IHSG. BI rate, nilai tukar rupiah terhadap USD dan dummy krisis berpengaruh signifikan negatif terhadap IHSG. Sedangkan variabel DAX, inflasi dan harga emas dunia tidak berpengaruh signifikan terhadap IHSG.
\end{abstract}

Kata kunci: indeks bursa luar negeri, indikator makroekonomi, krisis ekonomi global, analisis regresi berganda

\footnotetext{
${ }^{1}$ Alamat Korespondensi:

Email: adityasinggih@gmail.com
} 


\section{PENDAHULUAN}

Globalisasi yang terjadi dalam dimensi ekonomi menyebabkan meningkatnya tingkat ketergantungan antar negara dengan menjadi satunya ekonomi dunia, sehingga batas-batas negara yang sebelumnya dianggap sebagai barrier dianggap tidak ada. Dampaknya dibidang ekonomi diikuti oleh adanya liberalisasi dalam bidang perekonomian. Artinya, dalam pasar global saat ini, setiap investor dapat berinvestasi dimanapun berada (Wondabio, 2006). Terjadinya globalisasi menyebabkan semakin eratnya keterkaitan dan saling memengaruhi antar pasar modal di dunia. Oleh karena itu, perubahan di suatu bursa juga akan ditransmisikan ke bursa negara lain. Dalam hal ini biasanya bursa yang lebih besar akan memengaruhi bursa yang lebih kecil (Mansur, 2005).

Dalam berinvestasi di pasar modal, nilai harga saham menjadi pertimbangan yang sangat penting. Indeks berfungsi sebagai indikator tren pasar, artinya pergerakan indeks menggambarkan kondisi pasar pada saat pasar sedang aktif maupun sedang dalam kondisi lesu (Darmadji dan Fakhrudin, 2006). Menurut Blanchard (2006), indeks saham dipengaruhi antara lain oleh perubahan tingkat suku bunga bank sentral, keadaan ekonomi global, tingkat harga energi dunia, kestabilan politik suatu negara dan lain-lain. Selain itu kondisi makro perekonomian suatu negara merupakan salah satu faktor yang dapat memengaruhi kinerja perusahaan-perusahaan yang ada di negara tersebut (Samsul, 2008).
Kegiatan ekonomi dunia semakin berkait dan bergantung antara satu negara dengan negara lainnya, hampir tidak ada negara yang tidak mempunyai interaksi dengan dunia luar (Husnan, 2005). Fenomena ini dapat terlihat jelas dari adanya kejadian krisis ekonomi global salah satunya krisis keuangan dan moneter pada tahun 1997, Chakrabharti dan Roll (2002) menjelaskan krisis yang berawal dari isu nilai tukar di Thailand pada July 1997 secara cepat menyebar secara regional ke beberapa negara tetangga, terlihat dari jatuhnya pasar saham di beberapa negara seperti Indonesia (-71\%), Malaysia (-57\%), Filipina (-58\%), Singapura (-24\%), dan Korea Selatan (-72\%). Kejadian ini menyadarkan negaranegara di kawasan tersebut mengenai kerentanan terhadap efek tular (contagion effect) dari krisis ekonomi yang terjadi pada suatu negara di kawasan.

Hal yang sama pun terulang ketika dunia diguncang oleh krisis subprime mortgage pada tahun 2008 dan European seoverign debt crisis pada tahun 2011 yang berdampak pada penurunan berbagai indeks saham di dunia termasuh indeks saham di pasar modal Indonesia. Efek penularan (contagion effect) merupakan salah satu faktor yang muncul akibat mekanisme pasar yang semakin bebas akibat globalisasi. Yang et al. (2003) menemukan bahwa baik sebelum dan sesudah krisis, pasar modal di Amerika Serikat dan Jepang tetap memengaruhi pasar modal di Asia, salah satunya Indonesia. Gambar 1 memperlihatkan adanya kecenderungan penurunan nilai indeks saham IHSG dan indeks saham luar negeri pada periode krisis sedangkan pada periode tidak krisis indeks saham terlihat memiliki kecenderungan meningkat, namun demikian indeks saham terlihat memiliki kecenderung pergerakan yang hampir sama (comovement).

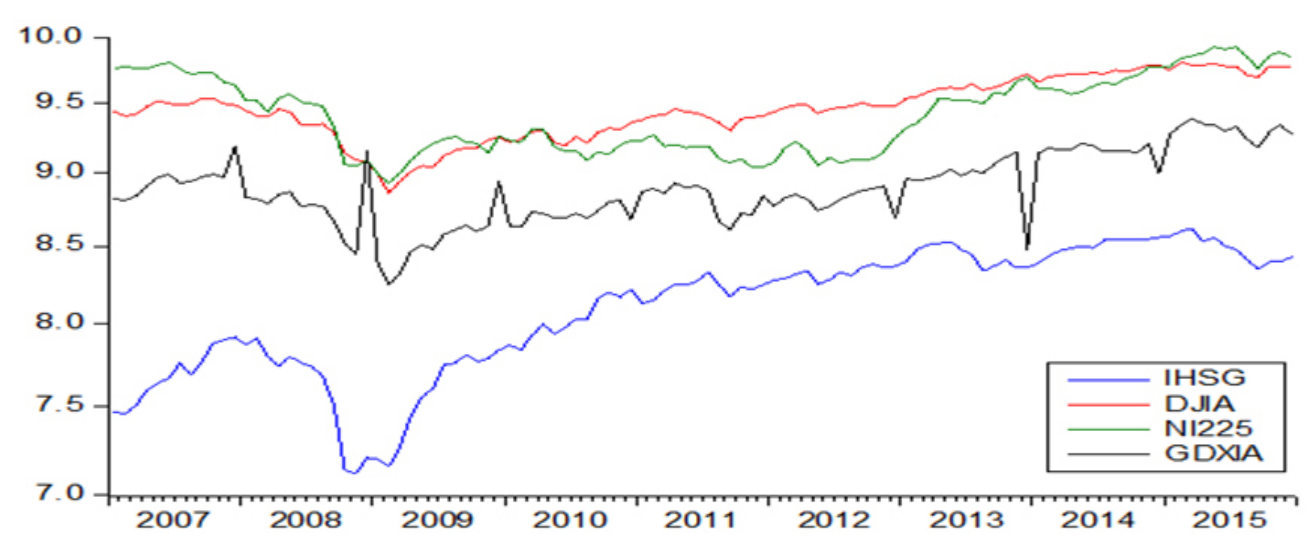

Gambar 1. Perkembangan IHSG dan Indeks bursa global periode 2007-2015 
Perkembangan IHSG dari tahun 2007-2015 menunjukan kecenderungan menguat akibat tekanan dari dalam dan luar negeri. Pada pertengahan tahun 2008, IHSG mengalami koreksi cukup dalam, IHSG ditutup pada level 1.355 poin atau melemah 50,64\% dibandingkan tahun sebelumnya, penurunan kinerja IHSG lebih disebabkan oleh gejolak eksternal, Gejolak eksternal bermula dari pecahnya bubble pasar keuangan global yang memicu terjadinya proses deleveraging dan berdampak pada perlambatan ekonomi global (BI, 2008). Pada tahun 2011 gejolak pasar keuangan global juga berdampak pada kinerja pasar saham domestik. Kondisi tersebut terefleksikan dalam pergerakan IHSG yang berfluktuasi sepanjang tahun. IHSG mencatat rekor tertinggi yakni sebesar 4.130 pada bulan Juli 2011. Namun, sentimen negatif akibat gejolak perekonomian dunia pada akhir triwulan III 2011 mengakibatkan investor asing melakukan penyesuaian portofolionya di pasar saham, yang menyebabkan pelemahan IHSG dan nilai tukar rupiah (BI, 2011).

Kondisi makro perekonomian suatu negara merupakan salah satu faktor yang dapat memengaruhi kinerja perusahaan-perusahaan yang ada di negara tersebut (Samsul, 2008) sehingga kondisi makro ekonomi berpengaruh terhadap pergerakan harga saham. Kemampuan investor dalam memahami dan meramalkan kondisi ekonomi makro di masa datang akan sangat berguna dalam pembuatan keputusan investasi yang menguntungkan sehingga investor harus memperhatikan beberapa indikator ekonomi makro yang bisa membantu mereka dalam memahami dan meramalkan kondisi ekonomi makro (Tandelilin, 2010). Indikator makro ekonomi yang sering kali dihubungkan dengan pasar modal adalah fluktuasi suku bunga, inflasi, kurs rupiah, harga minyak dunia, dan harga emas dunia (Surbakti et al. 2016).

Di Indonesia, kebijakan tingkat suku bunga dikendalikan secara langsung oleh Bank Indonesia melalui BI rate. $\mathrm{BI}$ rate merupakan respon bank sentral terhadap tekanan inflasi ke depan agar tetap berada pada sasaran yang telah ditetapkan (Witjaksono, 2010). BI rate adalah suku bunga kebijakan yang mencerminkan sikap atau stance kebijakan moneter yang ditetapkan oleh bank Indonesia dan diumumkan kepada publik. Kebijakan bunga rendah akan mendorong masyarakat untuk melakukan investasi daripada menabung, demikian pula sebaliknya.

Inflasi adalah proses kenaikan harga-harga umum secara terus-menerus, akibat dari inflasi secara umum adalah menurunnya daya beli masyarakat karena secara riel tingkat pendapatannya juga menurun (Putong dan Andjaswati, 2010). Dinamika dan perkembangan ekonomi berdampak pada peningkatan permintaan akan barang dan jasa yang merupakan salah satu penyebab inflasi (Russel, 2009).

Nilai tukar mata uang adalah jumlah dari mata uang suatu negara yang dapat ditukarkan per unit mata uang negara lain, atau dengan kata lain harga dari satu mata uang terhadap mata uang lain (Fabozzi dan Modigliani, 1995). Kurs merupakan salah satu indikator yang memengaruhi aktivitas di pasar saham maupun di pasar uang karena investor cenderung akan berhati-hati untuk melakukan investasi portofolio. Terdepresiasinya kurs rupiah terhadap mata uang asing khususnya dolar Amerika memiliki pengaruh yang negatif terhadap ekonomi dan pasar modal (Sitinjak dan Kurniasari, 2003).

Harga emas ditentukan oleh tingkat penawaran dan permintaan emas dari seluruh dunia. Permintaan emas oleh investor sebagai alat untuk diversifikasi aset untuk mengurangi risiko investasi karena emas merupakan alternatif investasi selain saham yang memiliki return di atas tingkat inflasi. Oleh karena itu, permintaan akan emas bertambah dan menyebabkan kenaikan harga emas (Sunariyah, 2006).

Berikut disajikan tinjauan penelitian terdahulu yang terkait dengan penelitian yang dilakukan. Ernawati et al. (2013) melakukan penelitian dengan analisis regresi yang bertujuan mengetahui pengaruh SBI, harga minyak dunia, harga emas dunia, kurs rupiah, indeks Nikkei 225 dan Indeks Dow Jones terhadap IHSG. Hasil penelitian menunjukan hanya harga emas dunia, indeks Nikkei 225 dan Indeks Dow Jones yang berpengaruh signifikan terhadap IHSG. Kowanda et al. (2013) menggunakan metode analisis regresi untuk meneliti pengaruh indeks global dan harga komoditas terhadap IHSG dan nilai tukar EUR/USD. Hasi penelitian menunjukan semua variabel berpengaruh terhadap IHSG dan nilai tukar EUR/USD. Kewal (2012) dalam penelitiannya menemukan bahwa tingkat inflasi, suku bunga SBI dan pertumbuhan PDB tidak berpengaruh signifikan, sedangkan kurs rupiah berpengaruh signifikan negatif terhadap IHSG. Menurut penelitian Krisna dan Wirawati (2013) hasil penelitian menunjukkan bahwa secara simultan tingkat inflasi nilai tukar rupiah dan tingkat suku bunga SBI berpengaruh signifikan pada 
IHSG sedangkan secara parsial hanya tingkat inflasi dan nilai tukar rupiah yang berpengaruh signifikan pada IHSG di BEI.

Gumilang et al. (2014) meneliti pengaruh variabel makro ekonomi, harga emas dan harga minyak dunia terhadap IHSG dengan menggunakan analisis regresi linear berganda. Hasil penelitiannya menyimpulkan bahwa suku bunga, kurs dan harga minyak berpengaruh signifikan negatif, sedangkan harga emas dunia berpengaruh signifikan positif terhadap IHSG. Variabel yang paling dominan memengaruhi IHSG adalah suku bunga. Hasil penelitian Budiantara (2012) mengenai pengaruh tingkat suku bunga, nilai kurs, dan inflasi terhadap IHSG bahwa inflasi tidak berpengaruh signifikan, sedangkan tingkat suku bunga dan nilai kurs berpengaruh signifikan negatif terhadap IHSG. Hasil penelitian yang dilakukan oleh Citra et al. (2012) menyimpulkan bahwa kurs, jumlah uang yang beredar, suku bunga, dan pertumbuhan ekonomi berpengaruh terhadap IHSG.

Wijayanti dan Kaluga (2013) melakukan penelitian yang bertujuan mengetahui pengaruh variabel makroekonomi dan indeks pasar modal dunia terhadap pergerakan IHSG. Hasil penelitiannya menyimpulkan bahwa GDP, DJIA, Nikkei 225 berpengaruf signifikan positif, sedangkan kurs dan SBI (Suku bunga Bank Indonesia) berpengaruh negatif terhadap IHSG. Penelitian yang dilakukan oleh Smith (2001) menyimpulkan harga emas dunia berpengaruh negatif terhadap pergerakan indeks harga saham di Amerika. Berbeda dengan Smith, Twite (2002) menemukan hasil bahwa emas adalah salah satu faktor yang memengaruhi secara positif pergerakan indeks saham di Australia.

Risiko berinvestasi di pasar modal pada prinsipnya terkait erat dengan terjadinya pergerakan harga saham. Terjadinya globalisasi menyebabkan semakin eratnya keterkaitan dan saling memengaruhi antar pasar modal di dunia. Krisis Subprime mortgage yang terjadi di Amerika dan European Sovereign Debt yang terjadi di Eropa berdampak luas ke seluruh negaranegara di dunia termasuk Indonesia, pengaruhnya terhadap financial market adalah efek shock terhadap pergerakan IHSG. Selain itu, pergerakan IHSG turut dipengaruhi oleh perubahan variabel makroekonomi. Dengan mengetahui dan memperhatikan faktor mana saja yang berpengaruh terhadap pergerakan IHSG maka diharapkan investor dapat mengambil keputusan di saat yang tepat. Penting bagi investor mengetahui pergerakan indeks saham karena menjadi acuan atau dasar bagi keputusan investasinya.

Tujuan dalam penelitian ini adalah menganalisis pengaruh faktor eksternal luar negeri yaitu indeks saham DJIA (Amerika), Nikkei 225 (Jepang), DAX (Jerman), harga emas dunia dan krisis ekonomi global terhadap IHSG dan menganalisis pengaruh faktor eksternal dalam negeri, yaitu BI rate, inflasi, dan kurs terhadap IHSG.

Fokus dari penelitian ini adalah untuk menganalisis pengaruh dari indeks harga saham global yaitu DJIA di Amerika, Nikkei 225 di Jepang dan DAX di Jerman, variabel makroekonomi, harga emas dunia dan krisis global terhadap pergerakan indeks IHSG. Untuk menghindari terlalu luasnya pembahasan, maka penelitian ini dibatasi pada beberapa hal, yaitu Indeks saham yang digunakan, yaitu Indonesia (IHSG), Amerika Serikat (DJIA) sebagai negara yang dianggap leader dalam perekonomian sekaligus sumber krisis Subprime mortgage, Jepang (Nikkei, 225) sebagai negara dengan perekonomian yang kuat di kawasan asia dan memiliki hubungan ekonomi yang kuat dengan Indonesia dan Jerman (DAX) sebagai negara dengan perekonomian kuat di kawasan Eropa sekaligus tempat terjadinya European Sovereign Debt crisis. Variabel makroekonomi yang digunakan adalah BI-rate, inflasi, nilai tukar dan harga emas dunia.

\section{METODE PENELITIAN}

Data yang digunakan dalam penelitian ini adalah data sekunder. Data sekunder tersebut berupa data runtun waktu dari Januari 2007 sampai dengan Desember 2015, yaitu indeks saham luar negeri dari yahoo finance, suku bunga Bank Indonesia, inflasi dan nilai tukar (kurs) rupiah terhadap USD dari Bank Indonesia (BI), dan harga emas dunia dari London Bullion Market Association (LBMA). Juga merujuk kepada literatur, buku-buku, internet, jurnal-jurnal, studi kepustakaan dan artikel lainnya yang berkaitan dengan penelitian ini. Data yang diperoleh selanjutnya dianalisis secara deskriptif dan kuantitatif. Analisis secara kuantitatif dilakukan dengan menggunakan model analisis regresi berganda dan persamaan dalam model diestimasi dengan menggunakan metode OLS (Ordinary Least Square) dengan menggunakan software Eviews 8. 
Langkah pertama adalah melakukan uji asumsi klasik yang terdiri dari uji multikoliniearitas, uji heteroskedastisitas, uji autokolerasi dan uji normalitas. Data yang diperoleh selanjutnya dianalisis secara deskriptif dan kuantitatif. Analisis secara kuantitatif dilakukan dengan menggunakan model analisis regresi berganda dan persamaan dalam model diestimasi dengan metode OLS dengan menggunakan software Eviews 7.

Model Regresi dapat dirumuskan sebagai berikut :

$$
\begin{gathered}
\mathrm{Y}_{\mathrm{t}}=\alpha+\beta_{1} \mathrm{DJIA}_{\mathrm{t}}+\beta_{2} \mathrm{NI}_{225}+\beta_{3} \mathrm{DAX}_{\mathrm{t}}+\beta_{4} \mathrm{BIRate}_{\mathrm{t}}+\beta_{5} \mathrm{INF} \\
\text { LASI }_{\mathrm{t}}+\beta_{6} \text { KURS }_{\mathrm{t}}+\beta_{7} \text { GOLD }_{\mathrm{t}}+\beta_{8} \text { Dummy }_{\mathrm{t}}+\mathrm{u}_{\mathrm{t}}
\end{gathered}
$$

Keterangan: $\mathrm{Y}_{\mathrm{t}}(\mathrm{IHSG}) ; \alpha$ (konstanta); $\beta_{\mathrm{t}}$ ( k o e fi s i e $\mathrm{n}$ regresi); DJIA (Indeks Dow Jone Industrial Average (poin)); NI225 (Indeks Nikkei 225 (poin)); DAX (Indeks Deutscher Aktien (poin)); BIRate (Suku Bunga Bank Indonesia (\%)); INFLASI (Tingkat Inflasi (\%)); KURS (Nilai tukar rupiah terhadap US\$); GOLD (Harga emas dunia); Dummy (Dummy krisis ( 1 = Krisis, $0=$ Tidak krisis) $)$; $\mathrm{u}_{\mathrm{t}}($ error term periode ke-t)

Langkah selanjutnya dilakukan pengujian hipotesis yang terdiri dari uji statistik $F$ dan uji statistik t. Uji hipotesis dilakukan dengan membandingkan nilai signifikansi pada hasil uji $\mathrm{F}$ dan uji t terhadap taraf nyata
0,05 Jika nilai signifikansi $<0,05$ dapat disimpulkan variabel independen memengaruhi variabel dependen. Selanjutnya uji koefisien determinasi (R2) untuk melihat seberapa jauh keragaman variabel dependen IHSG dapat dijelaskan oleh keragaman variabel independen. Jika semua uji terpenuhi maka model layak digunakan. Definisi operasional variabel selengkapnya pada Tabel 1. Setelah Hasil evaluasi ini akan memberikan implikasi manajerial bagi investor. Kerangka pemikiran konseptual penelitian dapat dilihat pada Gambar 2. Dari kerangka pemikiran konseptual, maka dibuat delapan hipotesis dalam penelitian ini:

H1: Indeks saham DJIA berpengaruh signifikan positif terhadap indeks saham IHSG

H2: Indeks saham Nikkei 225 berpengaruh signifikan positif terhadap indeks saham IHSG

H3: Indeks saham DAX berpengaruh signifikan positif terhadap indeks saham IHSG

$\mathrm{H} 4$ : BI rate memiliki berpengaruh signifikan negatif terhadap indeks saham IHSG

H5: Inflasi memiliki berpengaruh signifikan negatif terhadap indeks saham IHSG

H6: Kurs berpengaruh signifikan negatif terhadap indeks saham IHSG

H7: Harga emas dunia berpengaruh signifikan negatif terhadap indeks saham IHSG

H8: Dummy krisis berpengaruh signifikan negatif terhadap indeks saham IHSG

\begin{tabular}{|c|c|}
\hline Variabel & Definisi \\
\hline DJIA & $\begin{array}{l}\text { Indeks Saham Dow Jones Industrial Average (DJIA), mencakup } 30 \text { jenis saham industri yang tercatat di New } \\
\text { York Stock Exchange (NYSE) }\end{array}$ \\
\hline NI225 & $\begin{array}{l}\text { Indeks Saham Nikkei } 225 \text { (NI225), terdiri dari } 225 \text { perusahaan dengan saham-saham bluechip yang tercatat di } \\
\text { Tokyo Stock Exchange (TSE) }\end{array}$ \\
\hline DAX & $\begin{array}{l}\text { Indeks Saham Deutscher Aktien Index (DAX), mencakup } 30 \text { jenis saham yang tercatat di Börse Frankfurt } \\
\text { (Frankfurt Stock Exchange) }\end{array}$ \\
\hline $\mathrm{BI}$ rate & $\begin{array}{l}\text { Suku bunga Bank Indonesia (BI rate) yang mencerminkan sikap atau stance kebijakan moneter yang } \\
\text { ditetapkan oleh Bank Indonesia }\end{array}$ \\
\hline Inflasi & Tingkat Inflasi, menggambarkan tingkat harga barang dan jasa yang di konsumsi oleh masyarakat \\
\hline Kurs & $\begin{array}{l}\text { Kurs (Nilai tukar Rupiah terhadap USD), yaitu unit nilai tukar rupiah yang diperlukan untuk mendapatkan satu } \\
\text { unit mata uang asing (USD) }\end{array}$ \\
\hline Gold & Harga emas dunia adalah harga spot emas dunia yang terbentuk akibat akumulasi supply dan demand \\
\hline Dummy & $\begin{array}{l}\text { Dummy, yaitu menjelaskan periode pada saat terjadi krisis dan tidak krisis. } \text { Pada saat terjadi krisis }=1 \text { dan pada } \\
\text { saat tidak terjadi krisis }=0\end{array}$ \\
\hline
\end{tabular}

Tabel 1. Spesifikasi variabel 


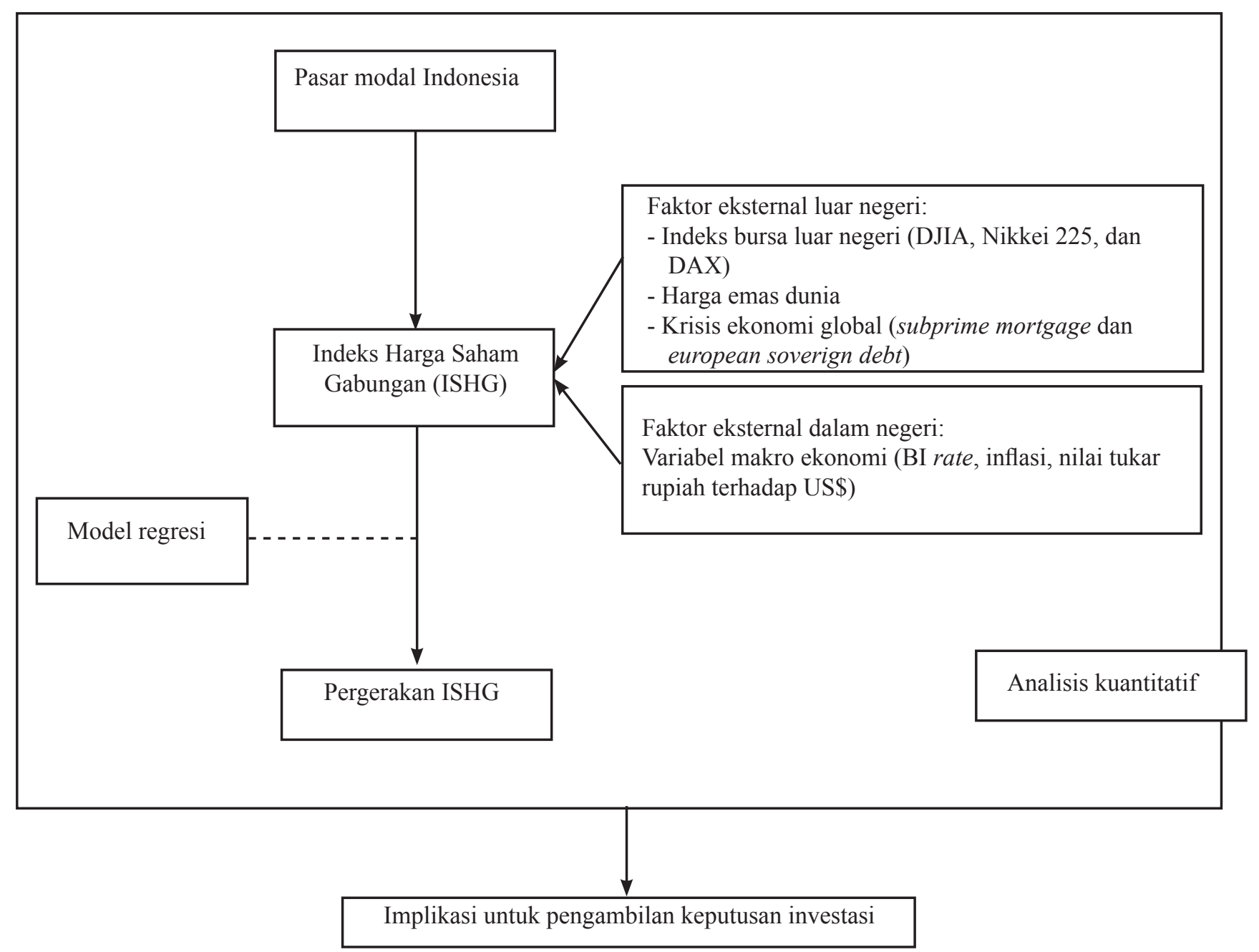

Gambar 2. Kerangka pemikiran penelitian (----- : alat bantu penelitian)

\section{HASIL}

\section{Uji Normalitas}

Berdasarkan Gambar 3 dapat dilihat bahwa hasil uji data normalitas dengan Jarque-Bera menunjukan nilai signifikansi sebesar 0,2165 lebih besar dari taraf nyata 0,05 sehingga dapat disimpulkan data terdistribusi normal.

\section{Uji Multikoineritas}

Multikolinieritas diuji dengan Variance Inflation Factor (VIF), hasil dari uji VIF ditampilkan pada Tabel 3 menunjukan tidak adanya variabel independen yang memiliki nilai VIF lebih besar dari 10 sehingga dapat disimpulkan tidak terdapat masalah multikolinieritas terhadap data yang diuji.

\section{Uji Heteroskedastisitas}

Gambar 4 menyajikan uji heteroskedastisitas menggunakan uji ARCH-LM. Nilai hasil uji ARCHLM menghasilkan signifikansi sebesar 0,8171 lebih kecil dari taraf nyata 0,05 , ini menunjukkan bahwa tidak ada efek ARCH GARCH dalam model atau dengan kata lain data bersifat homoskedastis, sehingga estimasi model dapat menggunakan regresi liniear berganda.

\section{Uji Autokorelasi}

Gambar 5 menyajikan hasil uji autokorelasi dengan Breusch-Godfey menghasilkan nilai probababilitas sebesar 0,3867 nilai ini lebih besar dari taraf nyata 0,05 sehingga dapat disimpulkan data terbebas dari masalah autokorelas. 


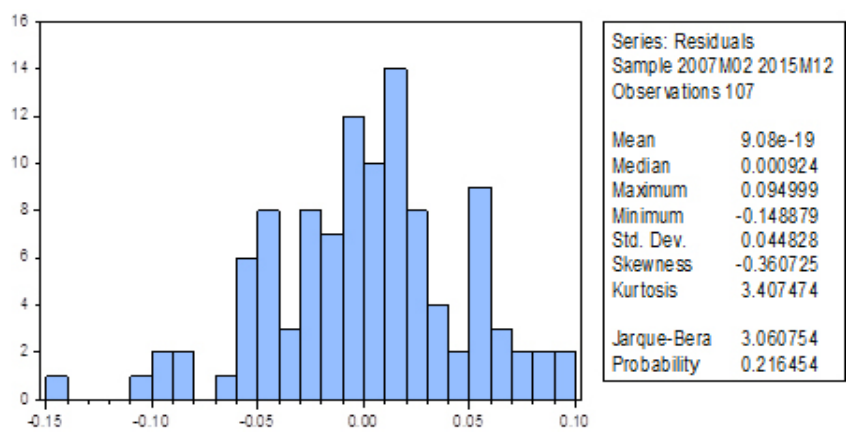

Gambar 3. Hasil Uji Normalitas

\begin{tabular}{llll}
\hline \hline F-statsic & 0.053790 & Prob. F(1,104) & 0.8171 \\
ObsR-squared & 0.054796 & Prob. Chi-Square(1) & 0.8149 \\
\hline \hline
\end{tabular}

Gambar 4. Hasil uji ARCH - LM

\begin{tabular}{llll}
\hline \hline F-statistic & 0.959546 & Prob. F(2,96) & 0.3967 \\
Obs*R-squared & 2097067 & Prob. Chi-Square(2) & 0.3505 \\
\hline \hline
\end{tabular}

Gambar 5. Hasil uji Breusch-Godfrey Serial Correlation LM Test

Tabel 2 menunjukan koefisien determinasi $\left(\mathrm{R}^{2}\right)$ persamaan IHSG sebesar $56 \%$, yang berarti $56 \%$ keragaman IHSG dapat dijelaskan oleh keragaman variabel independen DJIA, NI225, DAX, BIRate, INFLASI, KURS, GOLD, dan Dummy krisis, sisanya sebesar 44 persen dijelaskan oleh variabel lain diluar model. Nilai Probabilitas (F-statistic) sebesar 0,0000 lebih kecil dari taraf nyata 0.05 sehingga dapat disimpulkan bahwa seluruh variabel independen, secara bersama-sama berpengaruh terhadap IHSG.

Hasil dari uji t diperoleh tiga variabel independen yang memiliki nilai Probabilitas kurang dari taraf nyata 0,05 , yaitu variabel DAX, INFLASI dan GOLD, hal ini berarti variabel-variabel tersebut tidak berpengaruh signifikan terhadap IHSG seperti yang ditunjukan pada Tabel 3.

Persamaan hasil regresi dapat dituliskan dengan persamaan sebagai berikut :

$\mathrm{IHSG}=0,0142+0,4507$ DJIA $+0,314$ NI225 + 0,0413

DAX - 0,095 BIRate - 0,0041 INFLASI - 0,2876 KURS + 0,0623 GOLD - 0,0202 Dummy

\section{Pengaruh Secara Bersama-Sama Variabel Bebas Terhadap IHSG}

Hasil pengujian secara simultan menunjukan bahwa bahwa nilai Prob (F-statistic) sebesar 0,0000 lebih kecil dari taraf nyata 0,05 dapat disimpulkan bahwa DJIA, Nikkei 225, DAX, tingkat suku bunga BI, tingkat inflasi, nilai tukar rupiah terhadap USD, harga emas dunia dan Dummy krisis berpengaruh secara bersamasama terhadap nilai indeks saham IHSG.

\section{Pengaruh Faktor-faktor Eksternal Luar Negeri Terhadap IHSG}

Indeks Saham DJIA Terhadap IHSG

Berdasarkan penelitian indeks saham DJIA berpengaruh signifikan positif terhadap indeks saham IHSG. probabilitas variabel DJIA, yaitu 0,0030 lebih kecil dari taraf nyata 0,05 . Berdasarkan nilai tersebut maka variabel DJIA berpengaruh signifikan terhadap indeks saham IHSG. koefisien dari DJIA, yaitu 0,4507 , yang berarti jika kenaikan 0,01 indeks saham DJIA akan meningkatkan indeks saham IHSG sebesar 0,4507 ceteris paribus. Hasil yang diperoleh dari penelitian ini sesuai dengan hipotesis yang telah dibangun diawal yakni indeks saham DJIA berpengaruh signifikan positif terhadap indeks saham IHSG. Dari hasil penelitian diperoleh bahwa indeks saham DJIA berpengaruh signifikan terhadap indeks saham IHSG, ini membuktikan bahwa terdapat integrasi antar pasar saham di Amerika Serikat dengan pasar saham di Indonesia. Terintegrasinya pasar saham tersebut disebabkan oleh dampak dari globalisasi dan integrasi ekonomi sehingga perekonomian disuatu negara saling terkait. Oleh karena itu, perubahan di satu bursa saham akan ditransmisikan ke bursa saham negara lain, dimana bursa saham yang lebih kecil akan dipengaruhi oleh bursa saham yang lebih besar .

Indeks Saham Nikkei 225 Terhadap IHSG

Hasil penelitian variabel indeks saham Nikkei 225 berpengaruh signifikan dan positif terhadap indeks saham IHSG. Variabel indeks saham Nikkei 225 mempunyai probabilitas yang lebih kecil dari tarafnyata 0,05 , yaitu 0,0023 . Berdasarkan tersebut maka variabel indeks saham Nikkei 225 berpengaruh signifikan dan positif terhadap indeks saham IHSG. koefisien dari 
indeks saham Nikkei 225, yaitu 0,314, yang berarti jika indeks saham Nikkei 225 naik sebesar 0,01 maka akan meningkatkan indeks saham IHSG sebesar 0,314 ceteris paribus. Hasil yang diperoleh dari penelitian ini sesuai dengan hipotesis yang telah dibangun diawal yakni indeks saham Nikkei 225 berpengaruh signifikan positif terhadap indeks saham IHSG. Sama halnya dengan indeks saham DJIA, hasil penelitian ini membuktikan bahwa pasar saham di Jepang dengan pasar saham di Indonesia terjadi integrasi akibat dampak globalisasi dan integrasi ekonomi. Bursa saham di Jepang lebih besar dibandingkan dengan bursa saham di Indonesia sehingga indeks nikkei 225 akan mentransmisikan perubahan yang terjadi kepada indeks saham IHSG.

\section{Indeks Saham DAX Terhadap IHSG}

Berdasarkan hasil penelitian variabel indeks saham DAX tidak berpengaruh signifikan terhadap indeks saham IHSG. Variabel indeks saham DAX mempunyai probabilitas yang lebih kecil dari taraf nyata 0,05 , yaitu 0,1506 . Berdasarkan tersebut maka variabel indeks saham DAX tidak berpengaruh signifikan terhadap indeks saham IHSG dengan koefisien dari DAX yaitu 0,0413 . Hasil yang diperoleh pada penelitian ini sesuai dengan penelitian yang dilakukan oleh Topowijono (2015) yang menyatakan bahwa indeks saham DAX tidak berpengaruh signifikan terhadap Indeks Harga Saham Gabungan. Hal yang sama juga dikemukan oleh (Tamara dan Djazuli, 2012) dalam hasil penelitiannya menemukan bahwa indeks saham DAX tidak berpengaruh signifikan terhadap Indeks
Hasil penelitian ini bertolak belakang dengan hasil penelitian yang dilakukan oleh Prio (2010) yang menyatakan bahwa Deutsche Aktienindex berpengaruh signifikan negatif terhadap indeks saham IHSG dan Mailangkay (2013) yang menyatakan bahwa indeks saham DAX berpengaruh signifikan terhadap indeks saham IHSG. Tidak berpengaruhnya indeks saham DAX terhadap indeks saham IHSG disebabkan oleh keterkaitan ekonomi antara Jerman dan Indonesia tidak terlalu kuat, berdasarkan data data FDI Markets Financial Times nilai investasi Jerman di Indonesia hanya kurang dari satu persen dari nilai keseluruhan investasinya ke seluruh dunia.

\section{Harga Emas Dunia (Gold) Terhadap IHSG}

Hasil analisis terlihat bahwa variabel gold tidak berpengaruh signifikan terhadap indeks saham IHSG. Variabel gold mempunyai probabilitas yang lebih besar dari taraf nyata 0,05 , yaitu 0,5626 . Berdasarkan nilai tersebut maka variabel gold tidak berpengaruh signifikan terhadap indeks saham IHSG dengan nilai koefisien dari tingkat inflasi, yaitu -0,062281. Hasil yang diperoleh dari penelitian ini sesuai dengan hipotesis yang telah dibangun diawal yakni Harga emas dunia berpengaruh signifikan negatif terhadap indeks saham IHSG. Hasil penelitian ini sesuai dengan penelitian Lawrence (2013) yang menyatakan bahwa harga emas tidak berpengaruh signifikan terhadap IHSG dan Surbakti et al. (2016) menemukan bahwa harga emas tidak memiliki pengaruh yang signifikan terhadap volatilitas return indeks saham IHSG dikarenakan tujuan masyarakat membeli emas bukan untuk tujuan konsumtif, yakni sebagai perhiasan.

Tabel 2. Hasil estimasi persamaan indeks harga saham gabungan

\begin{tabular}{|c|c|c|c|c|c|c|}
\hline Variable & Coefficient & Std. Error & t-Statistic & Prob. & VIF & Description \\
\hline $\mathrm{C}$ & 0,0142 & 0,0060 & 2,3385 & 0,0214 & & \\
\hline DJIA & 0,4507 & 0,1447 & 3,1156 & 0,0024 & 1,9300 & Signifikan \\
\hline NI225 & 0,314 & 0,1001 & 3,1362 & 0,0023 & 1,8625 & Signifikan \\
\hline DAX & 0,0413 & 0,0285 & 1,4487 & 0,1506 & 1,1153 & Tidak Signifikan \\
\hline BIRATE & $-0,0950$ & 0,0312 & $-3,0477$ & 0,0030 & 1,3800 & Signifikan \\
\hline INFLASI & $-0,0041$ & 0,0071 & $-0,5809$ & 0,5626 & 1,2812 & Tidak Signifikan \\
\hline KURS & $-0,2876$ & 0,1053 & $-2,7321$ & 0,0075 & 1,2722 & Signifikan \\
\hline GOLD & 0,0623 & 0,0549 & 1,1349 & 0,2592 & 1,2497 & Tidak Signifikan \\
\hline DUMMY & $-0,0202$ & 0,0099 & $-2,0504$ & 0,0430 & 1,1325 & Signifikan \\
\hline \multicolumn{4}{|c|}{$R$-squared } & \multicolumn{3}{|c|}{0,563318} \\
\hline \multicolumn{4}{|c|}{ Adjusted R-squared } & \multicolumn{3}{|c|}{0,527671} \\
\hline \multicolumn{4}{|c|}{$F$-statistic } & \multicolumn{3}{|c|}{15,80247} \\
\hline \multicolumn{4}{|c|}{ Prob (F-statistic) } & \multicolumn{3}{|c|}{0,000000} \\
\hline
\end{tabular}




\section{Dummy Krisis Terhadap IHSG}

Hasil penelitian variabel dummy krisis berpengaruh signifikan negatifterhadap indeks saham IHSG. Variabel dummy krisis mempunyai nilai probabilitas yang lebih kecil dari taraf nyata 0,05 , yaitu 0,043 . berdasarkan nilai tersebut maka variabel dummy krisis berpengaruh signifikan terhadap indeks saham IHSG dengan nilai koefisien $-0,2023$, yang berarti pada saat terjadi krisis ekonomi global indeks saham IHSG akan lebih kecil sebesar 0,20223 ceteris paribus dibandingkan pada saat tidak terjadi krisis. Penelitian ini sesuai dengan penelitian yang dilakukan oleh Nezky (2013) yang menyatakan bahwa krisis Amerika memengaruhi pasar modal di Indonesia.

\section{Pengaruh Faktor-faktor Eksternal Luar Negeri Terhadap IHSG}

\section{Tingkat Suku Bunga (BI rate) Terhadap IHSG}

Berdasarkan hasil analisis terlihat bahwa BI rate berpengaruh signifikan negatif terhadap indeks saham IHSG. Variabel BI rate mempunyai probabilitas yang lebih kecil dari taraf nyata 0,05 , yaitu 0,0030 . Berdasarkan nilai tersebut, maka variabel $\mathrm{BI}$ rate berpengaruh signifikan terhadap indeks saham IHSG dengan koefisien dari BI rate, yaitu -0,0950, yang berarti jika BI rate naik sebesar 0,01 maka akan menurunkan indeks saham IHSG sebesar $-0,0950$ ceteris paribus. Hasil yang diperoleh dari penelitian ini sesuai dengan hipotesis yang telah dibangun diawal, yakni BI rate berpengaruh signifikan negatif terhadap indeks saham IHSG karena ketika suku bunga acuan dinaikan investor akan mengalihkan dananya dari pasar modal ke tabungan, deposito atau pasar obligasi. Hasil penelitian ini bertentangan dengan penelitian yang dilakukan oleh Enyah (2011) yang menyatakan bahwa tingkat suku bunga berpengaruh positif terhadap indeks saham di Ghana Stock Exchange. Hasil penelitian ini sesuai dengan penelitian yang dilakukan Thang (2009). Dalam penenlitiannya Thang (2009) menemukan bahwa tingkat suku bunga berpengaruh negatif terhadap indeks bursa saham di Malaysia.

\section{Inflasi Terhadap IHSG}

Hasil analisis terlihat bahwa variabel inflasi tidak berpengaruh signifikan terhadap indeks saham IHSG. Variabel inflasi mempunyai probabilitas yang lebih besar dari taraf nyata 0,05 , yaitu 0,5626 . Berdasarkan nilai tersebut maka variabel inflasi tidak berpengaruh signifikan terhadap indeks saham IHSG dengan nilai koefisien dari tingkat inflasi, yaitu $-0,0041$. Hasil yang diperoleh pada penelitian ini sesuai dengan hasil penelitian yang dilakukan oleh Rungsombudpornkul dan Limpanithiwat dan Rungsombudpornkul (2010) menyatakan bahwa inflasi tidak berpengaruh signifikan terhadap indeks SET50 di Thailand Stock Market. Hal yang sama juga dinyatakan oleh Banor (2014) bahwa inflasi tidak berpengaruh signifikan terhadap harga saham di Ghana Stock Exchange dan Ozbay (2009) menyatakan bahwa inflasi tidak berpengaruh signifikan terhadap return saham di Turki Stock Exchange. Pergerakan tingkat inflasi pada penelitian ini cendrung konstan dan bersifat bulanan sedangkan karakteristik investor di Bursa Efek Indonesia cendrung lebih bersifat spekulatif yakni lebih kepada aksi buy and sell bukan tipe investoryang melakukan aksi buy and hold sehingga investor tidak terlalu memperhatikan perubahan tingkat inflasi sebagai acuan untuk melakukan investasi pada saham yang pergerakannya harian

\section{Nilai Tukar (Kurs) Terhadap IHSG}

Hasil penelitian variabel kurs berpengaruh signifikan negatif terhadap indeks saham IHSG. Variabel kurs mempunyai nilai probabilitas yang lebih kecil dari taraf nyata 0,05 , yaitu 0,0075 . Berdasarkan nilai tersebut maka variabel kurs berpengaruh signifikan terhadap indeks saham IHSG dengan nilai koefisien -0,2876, yang berarti jika kurs naik sebesar 0,01 maka akan menurunkan indeks saham IHSG sebesar $-0,2876$ ceteris paribus. Hasil yang diperoleh dari penelitian ini sesuai dengan hipotesis yang telah dibangun diawal yakni kurs berpengaruh signifikan negatif terhadap indeks saham IHSG. Hasil penelitian yang sama juga dikemukakan oleh Muthia (2014) dan Naditia (2013) bahwa kurs rupiah memiliki pengaruh signifikan terhadap harga saham yang ada di Bursa Efek Indonesia hal tersebut dikarenakan kepemilikan saham di pasar modal Indonesia didominasi oleh investor asing. Hal yang sama juga dinyatakan dalam penelitian yang dilakukan oleh Erdogen dan Ozale (2005) bahwa pelemahan nilai mata uang dalam negeri (Turki) menghasilkan penurunan volatilitas retun saham periode sebelum dan saat krisis 1994.

\section{Implikasi Manajerial}

Dalam mengambil keputusan investasi, para investor perlu memperhatikan faktor eksternal luar negeri 
seperti indeks saham DJIA, Nikkei 225, harga emas dunia dan dan kondisi perekonomian global. Namun demikian, faktor eksternal luar negeri yang penting untuk diperhatikan adalah indeks saham DJIA, Nikkei 225 dan kondisi perekonomian global apakah sedang terjadi krisis atau tidak krisis. Apabila terjadi pergerakan pada indeks saham DJIA dan Nikkei 225 maka sebaiknya investor secara intensif memantau pergerakan indeks saham IHSG. Demikian pula jika terjadi krisis ekonomi global seyogyanya investor mencermati pergerakan indeks saham IHSG karena pada saat terjadi krisis ekonomi global nilai IHSG akan lebih rendah dibandingkan pada saat tidak terjadi krisis.

Selain faktor eksternal luar negeri, investor seyogyanya memperhatikan faktor eksternal dalam negeri seperti indikator makroekonomi yaitu tingkat suku bunga (BI rate), inflasi dan nilai tukar rupiah terhadap USD. Namun demikian, yang perlu diperhatikan adalah tingkat suku bunga dan nilai tukar rupiah terhadap USD. Ketika Bank Indonesia menaikan suku bunga acuannya, maka investor seyognya memperhatikan pergerakan indeks saham IHSG karena apabila suku bunga acuan mengalami kenaikan yang terlalu tinggi akan berdampak pada menurunnya indeks saham IHSG, begitu juga sebaliknya. Demikian pula, dengan terapresiasi atau terdepresiasinya nilai tukar rupiah terhadap USD, hal ini perlu dicermati oleh investor karena perubahan nilai tukar rupiah terhadap USD berpengaruh terhadap pergerakan indeks saham IHSG. Ketika terjadi depresiasi nilai tukar rupiah terhadap USD yang terlalu tinggi maka dapat menyebabkan menurunnya nilai indeks saham IHSG. Bagi Pemerintah atau Regulator hendaknya mengeluarkan kebijakankebijakan dengan mempertimbangkan variabel-variabel makroekonomi yang dapat memengaruhi IHSG dengan demikian dapat mendukung kemajuan dunia pasar modal Indonesia.

\section{KESIMPULAN DAN SARAN}

\section{Simpulan}

Pergerakan indeks saham IHSG yang ada di Bursa Efek Indonesia tidak hanya dipengaruhi oleh faktor dalam negeri tetapi juga dipengaruhi oleh faktor eksternal luar negeri. Salah satu faktor eksternal yang memengaruhi pergerakan indeks saham IHSG adalah variabel indeks saham luar negeri (Dow Jones Industrial Average, Nikkei 225 dan Deutscher Aktien Index), Harga emas dunia dan krisis ekonomi global. Indeks saham DJIA dan Nikkei 225 berpengaruh signifikan positif terhadap indeks saham IHSG. Hal ini berarti kenaikan atau penurunan indeks saham Dow Jones Industrial Average dan Nikkei 225 akan berpengaruh terhadap kenaikan dan penurunan indeks saham IHSG yang ada di Bursa Efek Indonesia. Krisis ekonomi global berpengaruh signifikan negatif terhadap indeks saham IHSG, hal ini berarti pada waktu terjadi krisis ekonomi global indeks saham IHSG akan lebih kecil dibandingkan pada waktu tidak terjadi krisis ekonomi global, sedangkan variabel indeks saham DAX tidak berpengaruh signifikan terhadap indek saham IHSG.

Faktor domestik yang berpengaruh terhadap indeks saham IHSG adalah variabel BI rate dan kurs rupiah terhadap USD. Variabel BI rate berpengaruh signifikan negatif terhadap indeks saham IHSG, hal ini berarti kenaikan dan penurunan BI rate akan menurunkan atau menaikan indeks saham IHSG. Sama halnya dengan BI rate, variabel kurs berpengaruh signifikan negatif terhadap indeks saham IHSG, hal ini berarti kenaikan kurs rupiah (terdepresiasinya rupiah) terhadap USD akan menurunkan nilai indeks saham IHSG, begitu juga sebaliknya, sedangkan varibel harga emas dunia (gold) dan inflasi terhadap indeks saham IHSG.

\section{Saran}

Pada penelitian ini data yang digunakan berupa data bulanan, penelitian selanjutnya disarankan menggunakan data harian untuk variabel indeks bursa saham, kurs dan harga emas dunia sehingga diperoleh data time series yang lebih panjang dan hasilnya akan lebih valid. Penelitian selanjutnya dapat menggunakan variabel makroekonomi yang lain seperti oil prices, money supply dan sebagainya untuk melihat pengaruhnya terhadap indeks saham IHSG. Penelitian ini juga dapat dikembangkan lagi dengan menambahkan berbagai informasi yang tidak tercatat secara ekonomi namun dapat memengaruhi kegiatan ekonomi dan memengaruhi keputusan investor terhadap investasinya seperti situasi politik atau penetapan kebijakan tertentu yang terjadi di lingkungan internasional. 


\section{DAFTAR PUSTAKA}

Blanchard O. 2006. Macroeconomics 4th edition. New Jersey: Pearson Prentice Hall.

Banor C. 2014. The effect of macroeconomic variables on stock market return in Ghana (2010-2013) [dissertation]. USA: Walden University.

[BI] Bank Indonesia. 2008. Laporan perekonomian Indonesia tahun 2008. http://www.bi.go.id [8 Maret 2016].

[BI] Bank Indonesia. 2011. Laporan perekonomian Indonesia tahun 2008. http://www.bi.go.id [8 Maret 2016].

Budiantara M. 2012. Pengaruh tingkat suku bunga, nilai kurs, dan inflasi terhadap indeks harga saham gabungan di bursa efek Indonesia periode tahun 2005-2010. Jurnal Sosiohumaniora 3(3): 57-66

Darmadji T, Fakhrudin MH. 2006. Pasar Modal di Indonesia Pendekatan Tanya Jawab. Jakarta: Salemba Empat.

Enyah RC. 2011. An Analysis of the effect of interest rate and exchange rate changes on stock market return: Empirical evidence of Ghana Stock Market [thesis]. Commonwealth Executive Master of Business Administration.

Erdogen E, Ozale. 2005. Effects of macroeconomics dynamics on stock returns: the case of the Turkish stock exchange market. Journal of Economic Cooperation.

Fabozzi FJ, Franco M. 1995. Capital Markets. New Jersey: Prentice Hall.

Gumilang RC, Hidayat RR, Endang MG. 2014. Pengaruh variabel makro ekonomi, harga emas dan harga minyak dunia terhadap indeks harga saham gabungan. Jurnal Administrasi Bisnis 14(2):1-9.

Kewal SS. 2012. Pengaruh inflasi, suku bunga, kurs, dan pertumbuhan PDB terhadap indeks harga saham gabungan. Jurnal Economia 8(1):53-64.

Krisna AAGA, Wirawati NGP. 2013. Pengaruh inflasi, nilai tukar rupiah, suku bunga SBI pada indeks harga saham gabungan di BEI. E-Jurnal Akuntansi Universitas Udayana 3(2):421-435.

Limpanthiwat K, Rungsombudpornkul. 2010. Relationship of Inflation and stock Price in Thailand. Umea: Umea School of Business.

Lawrence SS. 2013. Pengaruh variabel makroekonomi dan harga komoditas terhadap indeks harga saham gabungan di Indonesia. Finesta1(2): 1823.

Mansur M. 2005. Pengaruh indeks bursa global terhadap indeks harga saham gabungan (IHSG) pada bursa efek jakarta (BEJ) periode tahun 2000-2002. Sosiohumaniora 7(3):203-219.

Mailangkay J. 2013. Integrasi pasar modal Indonesia dan beberapa bursa di dunia (periode januari 2013-maret 2013). Jurnal EMBA 1(3): 722731.

Muthia VA. 2014. Analisis pengaruh variabel makroekonomi terhadap return saham indeks LQ45 (studi kasus pada BEI periode 2009-2013) [tesis]. Bogor: Institut Pertanian Bogor.

Naditia J. 2013. Analisis pengaruh variabel makroekonomi terhadap return dan volatilitas saham sektor pertambangan di Bursa Efek Indonesia [tesis]. Bogor: Institut Pertanian Bogor.

Nezky M 2013. Pengaruh krisis ekonomi Amerika terhadap bursa saham dan perdagangan Indonesia. Buletin Ekonomi Moneter dan Perbankan 15(3):89-103.

Ozbay E. 2009. The relationship between stock returns and macroeconomic factor: Evidence for Turkey [dissertasi]. Exeter: Bussines School University of Exter.

Putong I, Andjaswati ND. 2010. Pengantar Ekonomi Makro Edisi 2. Bogor : Mitra Media Wacana.

Russel S. 2009. Understanding Economic. Mason: South Western Cengage Learning.

Samsul M. 2008. Pasar modal dan Manajemen Portfoilio. Jakarta : Erlangga

Smith G. 2001. The price of gold and stock price indices for the united states. Available: www. ideas.repec.org

Sunariyah. 2006. Pengantar Pengetahuan Pasar Modal Edisi Kelima. Yogyakarta : UPP STIM YKPN.

Sitinjak ELM, Kurniasari W. 2003.Indikator-indikator pasar saham dan pasar uang yang saling berkaitan ditinjau dari pasar saham sedang bullish dan bearish. Jurnal Riset Ekonomi dan Manajemen $3(3)$.

Surbakti EH, Achsani NA, Maulana TNA. 2016. The Impact of macroeconomic variables on JCI's stock return volatility in pre and post Global economic crisis. International Journal of Scientific and Research Publications 6(3): 213219.

Tamara SF, Djazuli A. 2012. Pengaruh Dow Jones Industrial Average, Deutscher Aktienindex, Shanghai Stock Exchange Composite Index, 
dan Straits Times Index Terhadap Indeks Harga Saham Gabungan di Bursa Efek Indonesia (Periode 2010-2012). Jurnal Ilmiah Mahasiswa FEB 1(2).

Tandelilin E. 2010. Portofolio dan Investasi Teori dan Aplikasi. Edisi pertama. Yogyakarta: Kanisius.

Thang FZ. 2009. Impact of Interest rate and exchange rate on the stock market index in Malaysia: A cointegration analysis [thesis]. Penang: Universiti Sains Malaysia.

Topowijono. 2015. Pengaruh indeks harga saham global terhadap indeks harga saham gabungan (IHSG) studi pada Bursa Efek Indonesia. Jurnal Ilmiah Mahasiswa FEB 1(2).

Twite G. 2002. Gold Prices, Exchange Rates, Gold Stocks and the Gold Premium. Available :www. ideas.repec.org.

Wijayanti A, Kaluge D. 2013. Pengaruh beberapa variabel makroekonomi dan indeks pasar modal dunia terhadap pergerakan Indeks Harga Saham Gabungan (IHSG) di BEI. Jurnal Ilmiah Mahasiswa FEB 1(2).

Witjaksono AA. 2010. Analisis pengaruh tingkat suku bunga SBI, harga minyak dunia, harga emas dunia, kurs rupiah, indeks nikkei 225, dan indeks dow jones [tesis]. Semarang: Universitas Diponegoro.

Wondabio LS. 2006. Analisa hubungan Index Harga Saham Gabungan (IHSG) Jakarta (JSX), London (FTSE), Tokyo (Nikkei) dan Singapura (SSI). Di dalam: Simposium Nasional Akuntansi 9. Padang 23-26 Agustus 2006. 